https://helda.helsinki.fi

\title{
US monetary policy and China's exchange rate policy during the great recession
}

\section{Tervala, Juha}

2019-01

Tervala , J 2019 , ' US monetary policy and China's exchange rate policy during the great recession ' , International Journal of Finance and Economics , vol. 24 , no. 1 , pp. 113-130 . https://doi.org/10.1002/ij

http://hdl.handle.net/10138/321537

https://doi.org/10.1002/ijfe.1652

acceptedVersion

Downloaded from Helda, University of Helsinki institutional repository.

This is an electronic reprint of the original article.

This reprint may differ from the original in pagination and typographic detail.

Please cite the original version. 


\title{
U.S. Monetary Policy and China's Exchange Rate Policy during the Great Recession
}

\author{
Juha Tervala*
}

June 28, 2018

\begin{abstract}
I examine the transmission of expansionary U.S. monetary policy in cases where emerging economies-including China-peg their currencies to the dollar. I evaluate the value of the dollar peg as a fraction of consumption that households would be willing to pay for the dollar peg to remain as well off under the dollar peg as they would be under a flexible exchange rate. The value of the dollar peg is typically positive for the dollar bloc because the U.S. can no longer improve its terms of trade at the dollar bloc's expense. This provides a rationale for fixing the exchange rate. The dollar peg is typically harmful to the U.S., providing a rationale for criticism of China's exchange rate policy during the Great Recession.
\end{abstract}

Keywords: Dollar peg; dollar bloc; monetary policy; open economy macroeconomics; beggar-thy-neighbor

JEL classification: E32, E52, F30, F41, F44

${ }^{*}$ University of Helsinki, P.O. Box 17, 00014 University of Helsinki, Finland, juha.tervala@helsinki.fi. 


\section{Introduction}

The international transmission of U.S. monetary policy and China's exchange rate policy were topics of debate during the Great Recession. The U.S. Federal Reserve (Fed) was accused of competitive devaluation, which deliberately attempts to depreciate the dollar and stimulate the U.S. economy and-in particular-its exports at the expense of the rest of the world. Stiglitz (2008 \& 2010), for instance, argued that U.S. interest rate reductions are a beggarthy-neighbor policy as they have depreciated the dollar and helped to export the weakness of the U.S. economy to other countries.

Rajan (2011) argued that expansionary U.S. monetary policy represents a threat to the rest of the world. The argument goes as follows: U.S. interest rate reductions are followed by identical cuts everywhere, because no country wants its currency to appreciate strongly against the dollar. Consequently, the Fed ends up setting monetary policy also for the rest of the world. An expansionary U.S. monetary policy that is appropriate for the U.S. economy may be overly aggressive for emerging economies, where it leads to asset bubbles and inflation.

The Economist (2011) emphasized that 66 countries have either adopted the dollar as legal tender, pegged their currency to it or managed their exchange rate against it during the Great Recession. The dollar bloc's collective GDP was almost 9 trillion dollars, or about $14 \%$ of the world economy. The dollar bloc contains oil producers and emerging economies. Erceg et al. (2011) mention that various motivations for the dollar peg have been offered, including the desire to keep currencies weak and exports competitive and to avoid the adverse effects of exchange rate fluctuations on the balance sheets of domestic firms and households. The dollar peg also serves as a strong and easily understood anchor for monetary policy (Abed et al. 2003).

The largest member of the dollar bloc-by far-is China. It has been accused of currency manipulation to keep the yuan weak and its exports competitive during the global recession, when the Fed cut interest rates aggressively. Krugman (2010) argued that this was "the most distortionary exchange rate policy any major nation has ever followed", and the U.S. Treasury should have labelled China a currency manipulator. Importantly, political pressure to do so rose during the financial crisis (The Economist 2010).

In this paper, I use a New Keynesian open-economy model to examine the consequences of emerging economies'-including China's-dollar peg for the international transmission of a U.S. monetary policy shock (the deviation from the Taylor rule). I assume that the dollar bloc pegs the exchange rate to the dollar by following U.S. monetary policy. In addition, I assume that all export prices are set in U.S. dollars, which I refer to as dollar pricing. 
The assumption of dollar pricing is consistent with the empirical evidence of Goldberg and Tille (2008), who find that $99.8 \%$ of U.S. exports and $92.8 \%$ of U.S. imports are invoiced in dollars.

The implications of the dollar bloc's currency manipulation has been debated. This paper contributes to the debate by developing a novel way to measure the value of the dollar peg for the dollar bloc and the U.S. I measure the value of the dollar peg as a fraction of consumption that households would be willing to pay for the dollar peg to remain to be as well off under the dollar peg as under a flexible exchange rate.

The theme is related to the classic question of whether pegging the exchange rate is optimal. Since the publication of Obstfeld and Rogoff (2002), a strand of the recent literature has analyzed the optimal choice of the exchange rate regime in the face of monetary and real shocks based on rigorous welfare analysis. Lahiri et al. (2008) say that the classical finding in the world of sticky prices and perfect capital mobility is that a flexible (fixed) exchange rate is optimal if shocks are mainly real (monetary). This literature addresses the question of whether fixing the exchange rate during domestic shocks is optimal. However, the literature has not addressed the question of whether it is optimal for foreign countries to fix their exchange rates during domestic monetary shocks.

One of the main findings of this paper is that the value of the dollar peg is positive for the dollar bloc (including China), unless the cross-country substitutability (the elasticity of substitution between domestic and foreign goods) is very low, when U.S. interest rates fall. This provides a rationale for fixing the exchange rate to the dollar during a period of expansionary U.S. monetary policy. The positive value of the dollar peg stems from the ability of the U.S. to improve its terms of trade and consumption at the dollar bloc's expense under flexible exchange rates. The dollar peg prevents this, thereby increasing welfare. As Rajan (2011) suggested, the combination of the dollar peg and aggressive U.S. monetary policy can lead to an overheating of the dollar bloc. In the model, however, the dollar peg is optimal for the dollar bloc because it prevents a negative spillover effect of U.S. monetary expansion. A limitation of this paper is that the other types of shocks are not modelled. Therefore, so one should bear in mind that the optimal choice of exchange rate regime should depend not only on foreign monetary policy shocks but also on the other types of shocks.

McKinnon and Schnabl (2012) and Schnabl (2010) analyze the costs and benefits of the dollar peg for China, East Asia and the rest of the World and argue that it plays an important role in the pursuit of macroeconomic stability also in the case of U.S. monetary expansion. This paper supports the view that the benefits may exceed the costs, not because of macroeco- 
nomic stability, but despite the macroeconomic instability (higher output fluctuations) caused by the dollar peg.

Another of the main results of this paper is that the value of the dollar peg is negative for the U.S., unless the cross-country substitutability is very low. In the normal case, U.S. monetary policy is a beggar-thy-neighbor policy since the U.S. can raise welfare by improving its terms of trade. The dollar peg prevents this, so its value for the U.S. is negative.

If the cross-country substitutability is sufficiently low, the value of the dollar peg is positive for the U.S. Expansionary U.S. monetary policy under the flexible exchange rate causes a deterioration in the U.S. terms of trade in cases of very low cross-country substitutability. The dollar peg eliminates this and therefore the value of the dollar peg for the U.S. becomes positive when the cross-country substitutability is sufficiently low. However, the results show that for the typical parameter values of the cross-country substitutability, the value of the dollar peg is negative for the U.S. This provides a novel rationale for criticism of China's exchange rate policy during the Great Recession. It is, however, worth observing that expansionary U.S. monetary policy also increases U.S. welfare in the cases where the dollar bloc pegs the exchange rate to the dollar. The dollar peg just reduces the welfare gain of expansionary U.S. monetary policy to U.S. households.

The rest of the paper is organized as follows: Section 2 introduces the model, Section 3 discusses the parameterization of the model, Section 4 analyses the international transmission of U.S. monetary policy and the value of the dollar peg, and Section 5 concludes the paper.

\section{Model}

In this section, I develop a New Keynesian open-economy model in which the world economy consists of two countries: the U.S. and the dollar bloc. The dollar bloc refers to economies that have pegged their currencies to the U.S. dollar. A continuum of firms and households are indexed by $z \in[0,1]$. Fraction $n$ of them are located in the U.S., while fraction $1-n$ are located in the dollar bloc.

Each firm produces a differentiated good, and nominal price rigidity is introduced via the mechanism proposed by Calvo (1983). Empirical evidence points to there being asymmetry in international price setting. Goldberg and Tille (2008) find that $99.8 \%$ (92.8\%) of U.S. exports (imports) are invoiced in dollars. I assume that U.S. firms set a unified price across countries and set their export prices in dollars. Firms in the dollar bloc can "price-to-market" and set their export prices in dollars. The assumption of asymmetric export 
pricing implies that the exchange rate pass-through is zero in the U.S. and one in the dollar bloc for those goods whose prices cannot be adjusted. In the presentation that follows, if the equations are symmetric across countries, I present only the U.S. equation.

\subsection{Households}

\subsubsection{Preferences}

All households have identical preferences. The utility function of the representative U.S. household is given by

$$
U_{t}=E_{t} \sum_{s=t}^{\infty} \beta^{s-t}\left[\log C_{s}-\frac{\ell_{s}^{1+\frac{1}{\varphi}}}{1+\frac{1}{\varphi}}\right]
$$

where $E$ denotes the expectation operator, $\beta$ is the discount factor, $C_{t}$ is a consumption index, $\ell_{t}$ is the labor supply, and $\varphi$ is the Frisch elasticity of labor supply. The consumption index is given by

$$
C_{t}=\left[\kappa^{\frac{1}{\rho}}\left(C_{t}^{U S}\right)^{\frac{\rho-1}{\rho}}+(1-\kappa)^{\frac{1}{\rho}}\left(C_{t}^{D B}\right)^{\frac{\rho-1}{\rho}}\right]^{\frac{\rho}{\rho-1}}
$$

where $C_{t}^{U S}$ and $C_{t}^{D B}$ respectively denote U.S. household consumption of U.S. and the dollar bloc's goods, $\rho>0$ measures the elasticity of substitution between U.S. and the dollar bloc's goods and $\kappa$ denotes the share of U.S. goods in the consumption basket. ${ }^{1}$ I refer to $\rho$ as the cross-country substitutability. $^{2}$ The share of domestic goods in the U.S. consumption basket, $\kappa \equiv n \alpha$ $(0<\kappa<1)$, depends on the relative size of the U.S. economy $(n)$ and parameter $\alpha(\alpha>1)$, which captures the degree of home bias in consumption. Consumption of domestic $C_{t}^{U S}(z)$ and foreign $C_{t}^{D B}(z)$ goods are CES aggregates of the different brands of U.S. and the dollar bloc's goods

$C_{t}^{U S}=\left[n^{-\frac{1}{\theta}} \int_{0}^{n}\left(C_{t}^{U S}(z)\right)^{\frac{\theta-1}{\theta}} d z\right]^{\frac{\theta}{\theta-1}}, \quad C_{t}^{D B}=\left[(1-n)^{-\frac{1}{\theta}} \int_{n}^{1}\left(C_{t}^{D B}(z)\right)^{\frac{\theta-1}{\theta}} d z\right]^{\frac{\theta}{\theta-1}}$,

${ }^{1}$ The consumption index of the dollar bloc is

$$
C_{t}^{*}=\left[\kappa^{* \frac{1}{\rho}}\left(C_{t}^{* U S}\right)^{\frac{\rho-1}{\rho}}+\left(1-\kappa^{*}\right)^{\frac{1}{\rho}}\left(C_{t}^{* D B}\right)^{\frac{\rho-1}{\rho}}\right]^{\frac{\rho}{\rho-1}},
$$

where $\kappa^{*} \equiv n \alpha^{*}$ denotes the share of U.S. goods in the dollar bloc's consumption basket. Home bias requires $\alpha^{*}<1$.

${ }^{2}$ In case of $\rho=1$ the consumption index takes the Cobb-Douglas form: $C_{t}=$ $\frac{\left(C_{t}^{U S}\right)^{\kappa}\left(C_{t}^{D B}\right)^{1-\kappa}}{\kappa^{\kappa}(1-\kappa)^{1-\kappa}}$. 
where $\theta>1$ is the elasticity of substitution between goods produced in the same country.

The consumption indexes imply that households allocate their consumption according to the following equations:

$$
\begin{gathered}
C_{t}^{U S}(z)=\left[\frac{p_{t}^{U S}(z)}{P_{t}^{U S}}\right]^{-\theta}\left[\frac{P_{t}^{U S}}{P_{t}}\right]^{-\rho} \alpha C_{t}, \\
C_{t}^{D B}(z)=\left[\frac{p_{t}^{D B}(z)}{P_{t}^{D B}}\right]^{-\theta}\left[\frac{P_{t}^{D B}}{P_{t}}\right]^{-\rho}\left[\frac{1-\kappa}{1-n}\right] C_{t}, \\
C_{t}^{* U S}(z)=\left[\frac{p_{t}^{* U S}(z)}{P_{t}^{* U S}}\right]^{-\theta}\left[\frac{P_{t}^{* U S}}{P_{t}^{*}}\right]^{-\rho} \alpha^{*} C_{t}^{*}, \\
C_{t}^{* D B}(z)=\left[\frac{p_{t}^{* D B}(z)}{P_{t}^{* D B}}\right]^{-\theta}\left[\frac{P_{t}^{* D B}}{P_{t}^{*}}\right]^{-\rho}\left[\frac{1-\kappa^{*}}{1-n}\right] C_{t}^{*} .
\end{gathered}
$$

In these equations, asterisks indicate the dollar bloc's variables. Therefore, $C_{t}^{* U S}(z)$ and $C_{t}^{* D B}(z)$ respectively denote consumption of the differentiated U.S. and the dollar bloc's goods by the dollar bloc's households. All price indexes are expressed in the local currency, although U.S. firms set their export prices in dollars. Price $p$ represents dollar prices, and price $p^{*}$ represents foreign currency prices. The dollar price of U.S. and the dollar bloc's goods are denoted by $p_{t}^{U S}(z)$ and $p_{t}^{D B}(z)$, respectively. $p_{t}^{* U S}(z)$ and $p_{t}^{* D B}(z)$ are, respectively, the foreign currency price of U.S. and the dollar bloc's goods. $P_{t}^{U S}\left(P_{t}^{D B}\right)$ is the price indexes corresponding to U.S. (the dollar bloc's) consumption basket $C_{t}^{U S}\left(C_{t}^{D B}\right)$, and $P_{t}$ is the U.S. price index.

The U.S. price indexes are defined as follows:

$$
\begin{gathered}
P_{t}^{U S}=\left[n^{-1} \int_{0}^{n} p_{t}^{U S}(z)^{1-\theta} d z\right]^{\frac{1}{1-\theta}}, \quad P_{t}^{D B}=\left[(1-n)^{-1} \int_{n}^{1} p_{t}^{D B}(z)^{1-\theta} d z\right]^{\frac{1}{1-\theta}} \\
P_{t}=\left[\kappa\left(P_{t}^{U S}\right)^{1-\rho}+(1-\kappa)\left(P_{t}^{D B}\right)^{1-\rho}\right]^{\frac{1}{1-\rho}}
\end{gathered}
$$

The corresponding indexes for the dollar bloc are defined similarly.

\subsubsection{Budget constraints and financial markets}

Consider a cashless economy in which money is only a unit of account. The budget constraint of the U.S. household, in nominal terms, is given by

$$
D_{t}=\left(1+i_{t-1}\right) D_{t-1}+w_{t} \ell_{t}-P_{t} C_{t}+\pi_{t}
$$


$D_{t}$ denotes nominal bonds (that pay one dollar in period $t+1$ ) held at the end of period $t, i_{t-1}$ is the nominal interest rate on bonds between $t-1$ and $t, w$ is the nominal wage paid to a household, and $\pi$ denotes the household's share of the nominal profits (dividends) of U.S. firms. All U.S. (dollar bloc) households own an equal share of all U.S. (dollar bloc) firms.

The structure of the dollar bloc is identical to that of the U.S. economy, with one exception: U.S. households can hold only U.S. bonds, whereas households in the dollar bloc can hold both U.S. and dollar bloc bonds. Therefore, the foreign bond $\left(F^{*}\right)$, denominated in the currency of the dollar bloc, is not traded internationally.

The budget constraint of the representative household in the dollar bloc is

$$
\frac{D_{t}^{*}}{S_{t}}+F_{t}^{*}=\left(1+i_{t-1}\right) \frac{D_{t-1}^{*}}{S_{t}}+\left(1+i_{t-1}^{*}\right) F_{t-1}^{*}+w_{t}^{*} \ell_{t}^{*}-P_{t}^{*} C_{t}^{*}+\pi_{t}^{*},
$$

where $S_{t}$ is the nominal exchange rate, defined as the dollar price of the dollar bloc's currency (an increase in $S_{t}$ is a depreciation of the dollar). The global asset market-clearing condition for U.S. bonds requires $n D_{t}+(1-n) D_{t}^{*}=0$. The net supply of foreign bonds, on the other hand, is zero, because the dollar bloc has only one representative household.

Use of the Taylor rule implies that the model must be stationary. One way to render the model stationary is to assume that the domestic interest rate is increasing on the level of net foreign debt (Schmitt-Grohe and Uribe 2003). I include a risk premium for uncovered interest rate parity (UIP) that forces external debt in the long term to return to its initial level. Following Bergin (2006), I assume that lenders demand a higher rate of return on a country with a large external debt. The empirical evidence supports the view: highly indebted countries have higher real interest rates than countries with more positive external positions (Lane 2011). In addition, Bluedorn and Bowdler (2011) show that U.S. interest rate shocks cause deviations from UIP.

Households in the dollar bloc must be indifferent to holding U.S. or the dollar bloc bonds. The UIP with a risk premium $\left(\psi\left(\exp \left(D_{t}\right)-1\right)\right)$ is given by

$$
\left(1+i_{t}\right)=\left(1+i_{t}^{*}\right) \frac{E_{t}\left(S_{t+1}\right)}{S_{t}}+\psi\left(\exp \left(D_{t}\right)-1\right) .
$$

Equation (6) shows that households must pay a small cost if its bond holdings do not equal their initial steady-state level (i.e., zero).

The optimal behavior of households is governed by the following equations:

$$
\beta\left(1+i_{t}\right) E_{t}\left(\frac{P_{t} C_{t}}{P_{t+1} C_{t+1}}\right)=1,
$$




$$
\begin{gathered}
\beta\left(1+i_{t}^{*}\right) E_{t}\left(\frac{P_{t}^{*} C_{t}^{*}}{P_{t+1}^{*} C_{t+1}^{*}}\right)=1 \\
\ell_{t}=\left(\frac{w_{t}}{C_{t} P_{t}}\right)^{\varphi} \\
\ell_{t}^{*}=\left(\frac{w_{t}^{*}}{C_{t}^{*} P_{t}^{*}}\right)^{\varphi}
\end{gathered}
$$

Equations (7) and (8) are the Euler equations for optimal domestic and foreign consumption, respectively. Equations (9) and (10) show that the labor supply is an increasing function of real wages and a decreasing function of consumption.

\subsection{Monetary policy}

The U.S. central bank follows the Taylor rule with interest rate smoothing:

$$
i_{t}=\left(\left(\frac{P_{t}}{P_{t-1}}\right)^{\mu_{2}}\left(y_{t}^{g a p}\right)^{\mu_{3}}\right)^{1-\mu_{1}}\left(i_{t-1}\right)^{\mu_{1}} \epsilon_{t},
$$

where coefficients $\mu_{1}, \mu_{2}$ and $\mu_{3}$ are non-negative, $y_{t}^{g a p}$ is the output gap, and $\epsilon_{t}$ is an unpredictable shift in the monetary policy rule (zero mean white noise process). The output gap is defined as the deviation of output from the equilibrium level that would prevail in the absence of nominal rigidities. Monetary policy does not have an effect on output in the absence of nominal rigidities and therefore the deviation of output from the initial level actually measures the output gap.

To evaluate the consequences of the dollar peg, I contrast the flexible exchange rate case in which the central bank of the dollar bloc follows the Taylor rule, which is identical to (11), with an alternative in which the central bank pegs the exchange rate. Erceg et al. (2011) use this same approach. For simplicity, I assume that the dollar peg is perfectly credible and the central bank of the dollar bloc pegs the exchange rate by mimicking U.S. monetary policy $\left(i_{t}=i_{t}^{*}\right)$. The IMF (2013) has analyzed how a foreign monetary policy reaction to U.S. monetary policy depends on the exchange rate regime. The study cannot reject the possibility that the interest rate of dollar bloc countries reacts one to one to movements in U.S. monetary policy.

A typical view is that most dollar bloc countries are to some extent forced to follow U.S. monetary policy. Rogoff (2008) pointed out that during the U.S. financial crisis, "[d]ollar bloc countries have slavishly mimicked expansionary US monetary policy". However, the question of whether China has been able to implement an independent monetary policy is complicated. 
Koivu (2009) points out that China's monetary policy has relied on a fixed exchange rate, capital controls and a selection of administrative and quantitative policy tools. Ma and McCauley (2008) find that capital controls have proved effective. Cheung et al. (2008) find that U.S. interest rates have a weak effect on China. They argue that even with the dollar peg, China employs measures to retain its monetary policy independence.

Koivu (2009) points out that many features of China's monetary policy have changed in recent years. First, the role of interest rates has increased. In 2006-2007, the central bank increased the use of interest rates in an attempt to keep rising inflation under control. Second, since the summer of 2003, growing capital inflows have increased liquidity in China's financial markets and have complicated the conduct of monetary policy (Koivu 2009). Glick and Hutchison (2009) and Prasad (2008) find that the fixed exchange rate constrains China's monetary policy independence. Zhang (2009) shows that money supply has been a dominant policy instrument in China in the past decades, but the Taylor rule with interest rate smoothing that responses to the output gap and contemporary and expected inflation illustrates China's more recent monetary policy better.

Frankel (2010) finds that in 2007-2008, sterilization finally faltered and money growth became excessive. Bordo et al. (2012) find that China's sterilized foreign-exchange intervention failed to provide the central bank with a mechanism for systematically altering the exchange rate independently of its monetary policy. Moreover, Wolf (2008) argues that "Ben Bernanke is running the monetary policy of the People's Bank of China." Although the assumption that China follows U.S. monetary policy may be a bad reflection of reality, it nonetheless provides a simple way to peg the currency to the dollar.

\section{$2.3 \quad$ Firms}

\subsubsection{Profits}

All firms produce a differentiated good. The production function of the representative U.S. firm is

$$
y_{t}(z)=\ell_{t},
$$

where $y_{t}(z)$ is the total output of firm $z$, and $\ell_{t}$ is the labor input.

The profits of the U.S. firm are given by

$$
\pi_{t}(z)=p_{t}^{U S}(z) y_{t}^{d}(z)-w_{t} \ell_{t} .
$$

The firm takes into account the production function (12) and the demand 
curve for its products

$$
y_{t}^{d}(z)=\left[\frac{p_{t}^{U S}(z)}{P_{t}^{U S}}\right]^{-\theta}\left[\frac{P_{t}^{U S}}{P_{t}}\right]^{-\rho} \kappa C_{t}+\left[\frac{p_{t}^{U S}(z)}{P_{t}^{U S}}\right]^{-\theta}\left[\frac{P_{t}^{U S}}{S_{t} P_{t}^{*}}\right]^{-\rho}(1-n) \alpha^{*} C_{t}^{*} .
$$

The profits of the U.S. firm, therefore, can be written as

$$
\begin{aligned}
\pi_{t}(z)= & \left(p_{t}^{U S}(z)-w_{t}\right) \times \\
& {\left[\left[\frac{p_{t}^{U S}(z)}{P_{t}^{U S}}\right]^{-\theta}\left[\frac{P_{t}^{U S}}{P_{t}}\right]^{-\rho} \kappa C_{t}+\left[\frac{p_{t}^{U S}(z)}{P_{t}^{U S}}\right]^{-\theta}\left[\frac{P_{t}^{U S}}{S_{t} P_{t}^{*}}\right]^{-\rho}(1-n) \alpha^{*} C_{t}^{*}\right] . }
\end{aligned}
$$

As mentioned in Section 2, firms in the dollar bloc can "price-to-market" and set their prices in the currency of the buyer. The total output of the representative firm in the dollar bloc, $y_{t}^{*}(z)$, is divided between the output sold in the U.S., $v_{t}^{*}(z)$, and the output sold in the dollar bloc, $x_{t}^{*}(z)$. Its profits are given by

$$
\pi_{t}^{*}(z)=\left(p_{t}^{D B}(z) v_{t}^{*}(z)\right) / S_{t}+p_{t}^{* D B}(z) x_{t}^{*}(z)-w_{t}^{*} \ell_{t}^{*}(z) .
$$

The demand for the dollar bloc's goods are given by

$$
\begin{aligned}
& v_{t}^{*}(z)=\left[\frac{p_{t}^{D B}(z)}{P_{t}^{D B}}\right]^{-\theta}\left[\frac{P_{t}^{D B}}{P_{t}}\right]^{-\rho} n\left[\frac{1-\kappa}{1-n}\right] C_{t}, \\
& x_{t}^{*}(z)=\left[\frac{p_{t}^{* D B}(z)}{P_{t}^{* D B}}\right]^{-\theta}\left[\frac{P_{t}^{* D B}}{P_{t}^{*}}\right]^{-\rho}\left(1-\kappa^{*}\right) C_{t}^{*} .
\end{aligned}
$$

Equations (16) and (17) show demand in the U.S. and in the dollar bloc, respectively.

\subsubsection{Price setting}

U.S. firms maximize their profits, specified in Equation (14), with respect to $p_{t}^{U S}(z)$. In the absence of price rigidities, this would imply

$$
p_{t}^{U S}(z)=\frac{\theta}{\theta-1} w_{t} .
$$

Under the Calvo pricing assumption, each firm may reset its price in any given period with a probability of $1-\gamma$, independently of other firms and the elapsed time since the last adjustment. When setting a new price in period $t$, the firm seeks to maximize the discounted present value of expected real profits

$$
\max _{p_{t}^{U S}(z)} V_{t}(z)=E_{t} \sum_{s=t}^{\infty} \gamma^{s-t} Q_{t, s} \frac{\pi_{s}(z)}{P_{s}}
$$


where $Q_{t, s}$ is a stochastic discount factor between periods $t$ and $s$. The U.S. firm's optimization problem results in the following pricing rule:

$$
p_{t}^{U S}(z)=\left(\frac{\theta}{\theta-1}\right) \frac{E_{t} \sum_{s=t}^{\infty} \gamma^{s-t} Q_{t, s} A_{s} w_{s}}{E_{t} \sum_{s=t}^{\infty} \gamma^{s-t} Q_{t, s} A_{s}}
$$

where

$$
A_{s}=\left(\frac{1}{P_{s}^{U S}}\right)^{-\theta}\left(\frac{P_{s}^{U S}}{P_{s}}\right)^{-\rho}\left(\frac{k C_{s}}{P_{s}}\right)+\left(\frac{1}{P_{s}^{U S}}\right)^{-\theta}\left(\frac{P_{s}^{U S}}{E_{s} P_{s}^{*}}\right)^{-\rho}\left(\frac{(1-n) \alpha^{*} C_{s}^{*}}{P_{s}}\right) .
$$

The log-linear version of Equation (19) can be written as

$$
\hat{p}_{t}^{U S}(z)=\beta \gamma E_{t} \hat{p}_{t+1}^{U S}(z)+(1-\beta \gamma) \hat{w}_{t},
$$

where percentage changes from the initial steady state (denoted by the subscript zero) are denoted by hats (e.g., $\left.w_{t}=d w_{t} / w_{0}\right)$. The optimal price is the weighted average of current and future nominal marginal costs.

The representative firm in the dollar bloc seeks to maximize

$$
\max _{p_{t}^{D B}(z), p_{t}^{* D B}(z)} V_{t}^{*}(z)=E_{t} \sum_{s=t}^{\infty} \gamma^{s-t} Q_{t, s}^{*} \frac{\pi_{s}^{*}(z)}{P_{s}^{*}} .
$$

The pricing rules are given by

$$
\begin{aligned}
& p_{t}^{D B}(z)=\left(\frac{\theta}{\theta-1}\right) \frac{E_{t} \sum_{s=t}^{\infty} \gamma^{s-t} Q_{t, s}^{*}\left(\frac{1-\kappa}{1-n}\right)\left(\frac{C_{s}}{P_{s}}\right)\left(\frac{1}{P_{s}^{D B}}\right)^{-\theta}\left(\frac{P_{s}^{D B}}{P_{s}}\right)^{-\rho} w_{s}^{*}}{E_{t} \sum_{s=t}^{\infty} \gamma^{s-t} Q_{t, s}^{*}\left(\frac{1-\kappa}{1-n}\right)\left(\frac{C_{s}}{P_{s}}\right)\left(\frac{1}{P_{s}^{D B}}\right)^{-\theta}\left(\frac{P_{s}^{D B}}{P_{s}}\right)^{-\rho}\left(\frac{1}{S_{s}}\right)}, \\
& p_{t}^{* D B}(z)=\left(\frac{\theta}{\theta-1}\right) \frac{E_{t} \sum_{s=t}^{\infty} \gamma^{s-t} Q_{t, s}^{*}\left(\frac{\alpha^{*} C_{s}^{*}}{P_{s}^{*}}\right)\left(\frac{1}{P_{s}^{* D B}}\right)^{-\theta}\left(\frac{P_{s}^{*} D B}{P_{s}^{*}}\right)^{-\rho} w_{s}^{*}}{E_{t} \sum_{s=t}^{\infty} \gamma^{s-t} Q_{t, s}^{*}\left(\frac{\alpha^{*} C_{s}^{*}}{P_{s}^{*}}\right)\left(\frac{1}{P_{s}^{* D B}}\right)^{-\theta}\left(\frac{P_{s}^{* D B}}{P_{s}^{*}}\right)^{-\rho}} .(21)
\end{aligned}
$$

The log-linear versions of these equations can be expressed as

$$
\begin{gathered}
\hat{p}_{t}^{D B}(z)=\beta \gamma E_{t} \hat{p}_{t+1}^{D B}(z)+(1-\beta \gamma)\left(\hat{w}_{t}^{*}+S_{t}\right) . \\
\hat{p}_{t}^{* D B}(z)=\beta \gamma E_{t} \hat{p}_{t+1}^{* D B}(z)+(1-\beta \gamma) \hat{w}_{t}^{*} .
\end{gathered}
$$

Equation (22) shows that the optimal price of the dollar bloc's good sold in the U.S. is the weighted average of current and future nominal marginal costs and the exchange rate. 


\subsection{Symmetric equilibrium}

Consider a symmetric case in which every firm that changes its price in any given period chooses the same price and output. This implies that in each period, a fraction of firms $(1-\gamma)$ sets a new price, and the price of the remaining fraction remains unchanged.

The consolidated budget constraint of the home economy is derived with Equations (4) and (13):

$$
P_{t} C_{t}=p_{t}^{U S}(z) y_{t}(z)+\left(1+i_{t-1}\right) D_{t-1}-D_{t} .
$$

The corresponding foreign equation, which takes into account the global asset market-clearing condition for U.S. bonds and that the net supply of the bond in the dollar bloc is zero, is

$P_{t}^{*} C_{t}^{*}=\left(p_{t}^{D B}(z) v_{t}^{*}(z)\right) / S_{t}+p_{t}^{* D B}(z) x_{t}^{*}(z)-\left(1+i_{t-1}\right) \frac{n}{1-n} \frac{D_{t-1}}{S_{t}}+\frac{n}{1-n} \frac{D_{t}}{S_{t}}$.

I use a log-linearized version of the model around a symmetric steady state in which initial net foreign assets are zero $\left(D_{0}=0\right)$. In this case, taking also into account that all prices are the same in the initial equilibrium, equation (24) implies that $C_{0}=y_{0}(z)$. This and equations (9), (12) and (18) imply that the initial level of employment is given by

$$
y_{0}(z)=\ell_{0}=\left(\frac{\theta-1}{\theta}\right)^{\frac{1}{1+\frac{1}{\nu}}}
$$

Equilibrium is defined as sequences of variables that clear the labor and goods markets in both countries every period and satisfy pricing rules and intertemporal budget constraints.

\section{Parameter values}

The parameterization of the model, shown in Table 1 , is chosen to match features of the U.S. and the dollar bloc during the Great Recession. Periods are interpreted as quarters. The discount factor $\beta$ is set to 0.99. As mentioned in Section 2, the Economist (2011) found that the dollar bloc's collective GDP was almost 9 trillion dollars at that time. U.S. GDP was roughly 14 trillion dollars at that time. Consequently, the relative size of the U.S. economy $(n)$ is set to 0.6. In comparison, Erceg et al. (2011) set the size of the U.S. economy relative to the dollar bloc to 0.55 , but argue that their parameterization overstates the size of the dollar bloc. 
Table 1: Baseline parameterization

\begin{tabular}{c|c|c|c} 
Param. & Description & Value & Reference \\
\hline$\beta$ & Discount factor & 0.99 & \\
\hline$n$ & Relative size of the U.S. & 0.6 & Economist (2011), World Bank (2016) \\
\hline$\alpha$ & Home bias parameter & 1.4 & World Bank (2016) \\
\hline$\alpha^{*}$ & Home bias parameter & 0.4 & Clarida et al. (2000) \\
\hline$\mu_{1}$ & Interest rate smoothing & 0.8 & Taylor (1993) \\
\hline$\mu_{2}$ & Inflation coefficient & 1.5 & Taylor (1993) \\
\hline$\mu_{3}$ & Output gap coefficient & $0.5 / 4$ & Bergin (2006) \\
\hline$\psi$ & Risk premium parameter & 0.004 & Rotemberg and Woodford (1992) \\
\hline$\theta$ & Within-country subst. & 6 & Keane and Rogerson (2012) \\
\hline$\varphi$ & Frisch elasticity & 1 & Gopinath and Rigobon (2008) \\
\hline$\gamma$ & Price rigidity & 0.75 & Hooper et al. (2000), Feenstra et al. (2017) \\
\hline \hline
\end{tabular}

The home bias parameter $\alpha$ is set to match the empirically observed import-to-output ratio in the U.S. The ratio averaged $16 \%$ in the U.S. in 2008-2012 (World Bank 2016). Therefore, $\alpha$ is set $0.84 / 0.6$, so the importto-output ratio $(1-n \alpha)$ is $16 \%$. I assume that the per-capita levels of output and consumption are identical across regions. This requires that $\alpha^{*}=(1-\alpha n) /(1-n)=0.4$. The implied import-to-output ratio $\left(\kappa^{*}=\alpha^{*} n\right)$ in the dollar bloc is $24 \%$, whereas the empirically observed ratio averaged $25 \%$ in China in 2008-2012 (World Bank 2016).

The interest rate smoothing parameter $\left(\mu_{1}\right)$ is set to 0.8 , which is consistent with Clarida et al. (2000). Based on Taylor (1993), $\mu_{2}$ is set to 1.5 and $\mu_{3}$ is set to $0.5 / 4$. Zhang (2009) finds that before China returned to the tight dollar peg in mid-2008 the interest rate smoothing parameter was 0.76 and the weight of inflation (the annual output gap) was 0.94 (0.47). Therefore, the Taylor rule with interest rate smoothing is not an unrealistic description of monetary policy in China.

Based on Bergin (2006), the risk premium in UIP $(\psi)$ is set to 0.004 . This implies that a net foreign debt of $10 \%$ of output increases the domestic interest rate by four basis points relative to that of the foreign country. Based on Rotemberg and Woodford (1992), the within-country substitutability $(\theta)$ is set to 6 . The Frisch elasticity $(\varphi)$ is set to 1 , based on Keane and Rogerson (2012). These values are widely used in the business cycle literature.

The price rigidity parameter $(\gamma)$ governs the strength and duration of the expenditure switching effect. Consequently, it is important to set the parameter to match the empirical evidence on the price rigidities of internationally 
traded goods. Gopinath and Rigobon (2008) find that the trade-weighted median price duration is 12.8 (10.6) months for U.S. exports (imports). I therefore set $\gamma$ to 0.75 , which implies that there is an average delay between price adjustments of four quarters.

The cross-country substitutability $\rho$ is a key parameter for the theme of this paper. Tille (2001) shows that it is a key parameter in determining the international welfare effects of monetary policy. Feenstra et al. (2017) find that the median estimates of the micro elasticity (substitution between different import suppliers) between U.S. and foreign countries is between 3.2 and 4.1, whereas the macro elasticity (substitution between home production and imports) is significantly lower in up to one-half of the goods they analyzed. They argue, however, that the macro elasticity is not as low as one sometimes found using macro methods.

Hooper et al. (2000) estimate the short- and long-term price elasticities of exports and imports for G7 countries. They find that the sum of the short-term elasticities for imports and exports exceeds one in absolute value only in the U.S. For the U.S. it is 1.1; for Japan, it is 0.6. The elasticities, however, increase over time and typically exceed one in the long term. The sum of the long-term elasticities for the U.S. is 1.8; for Japan, it is 1.3.

I set $\rho$ to 2 , which is the near the middle of the estimates for the U.S. provided by Feenstra et al. (2017) and Hooper et al. (2000). However, I analyze the sensitivity of key results as I vary it from 0.5 to $6 .^{3}$

\section{International transmission of U.S. mone- tary policy}

\subsection{U.S. monetary policy under flexible exchange rates}

The main innovation of this paper is to evaluate the value of the dollar peg relative to the flexible exchange rate. Therefore, I begin by analyzing the international effects of a U.S. interest rate cut under flexible exchange rates. Many of these results are not relevant per se; they provide a useful benchmark to put into context the results of the following section.

I analyze the effects of a decrease of 100 basis points (bp) in the annual U.S. interest rate. The empirical studies typically analyze the effects of 100 basis point changes in the interest rate and therefore the assumption makes it easy to compare my results with the empirical findings. The 100 basis point

\footnotetext{
${ }^{3}$ I solved the model using the algorithm developed by Klein (2000) and McCallum (2001).
} 
reduction in the interest rate might not seem to be a realistic description of the response of the Fed to the crisis: the interest rate was driven all the way to zero and the Fed has indicated that it will pursue the zero rate interest policy for a long time. A shock to the monetary policy rule may not be an optimal description of reality during the Great Recession, but it is a simple way to model the loose monetary policy of the Fed. Figure 1 (on page 36) shows the actual Fed funds rate and the interest rate implied by the Taylor rule, using the same parameters as in the simulations. ${ }^{4}$ It shows that the monetary policy response of the Fed to the Great Depression can be understood mostly as a response to negative demand shocks rather than as a deviation from the Taylor rule. However, it shows also that the Fed caused a monetary policy shock in 2008, defined as the deviation from the Taylor rule, of which size was 184 basis point in mid-2008. In 2009, the interest rate was roughly in line with the Taylor rule.

The dynamic effects of this exercise appear in panels (a)-(h) of Figure 2 (on page 37). In all figures, the horizontal axis denotes time. The vertical axis typically shows percentage deviations from the initial steady state. ${ }^{5}$ The responses of inflation and interest rates, however, are expressed as percentage point deviations in annual terms. The U.S. terms of trade, shown in Figure 2(d), are defined as the Calvo-weighted relative price of U.S. exports in terms of U.S. imports. If the index rises, the U.S. terms of trade improve.

Figure 2(f) shows the response of the dollar bloc's interest rate is in practise zero. Caceres et al. (2016) find that the response of the foreign interest rate to a 100 basis point change in the U.S. federal funds rate under a fully flexible regime is indistinguishable from zero.

Figure 2(c) demonstrates that a U.S. interest rate reduction depreciates the nominal exchange rate. The U.S. interest rate is temporarily low relative to the dollar bloc's interest rate. Since UIP holds, the exchange rate must depreciate to a point where it will appreciate until it reaches the steady-state level. Bluedorn and Bowdler (2011) find that a 100 basis point change in the U.S. t-bill rate causes a contemporaneous movement of the dollar which exceeds one percentage point, for example, the change versus the British pound is $1.3 \%$. The results of this paper regarding the exchange rare movement are in line with these findings.

In the dollar pricing case, the exchange rate pass-through to import price is one in the dollar bloc and zero in the U.S. for those goods whose prices cannot be adjusted. In the dollar bloc, the dollar's depreciation implies

\footnotetext{
${ }^{4}$ The Taylor rule is now $i_{t}=\mu_{1} i_{t-1}+\left(1-\mu_{1}\right)\left[\left(r^{*}+2\right)+\mu_{2}\left(\pi_{t}-2\right)+\mu_{1} y_{t}^{g a p}\right]$, where $r^{*}$ is the equilibrium real interest rate (set to $2 \%$ ) and $\pi_{t}$ is 4 -quarter core inflation.

${ }^{5}$ The change in bond holding, whose initial steady state is zero, is expressed as a deviation form initial consumption.
} 
that U.S. goods become cheaper relative to the dollar bloc's goods. This shifts demand toward U.S. goods and away from the dollar bloc's goods. This expenditure switching effect increases U.S. output and tends to decrease the dollar bloc's output. Due to a low cross-country substitutability, this effect is relatively weak and dominated by the direct demand increase of U.S. households. The exchange rate pass-through is zero in the U.S., and a rise in U.S. demand increases both the U.S. and dollar bloc's outputs. Output, therefore, also increases in the dollar bloc in the short term.

A low real interest rate raises consumption in both regions. In the dollar pricing case, the dollar's depreciation reduces the dollar bloc's earnings in their own currencies (see Equation (15)). This and the expenditure switching effect increase relative U.S. consumption. U.S. households smooth consumption over time and save part of this income by running a current account surplus in the short term (Figure $2(\mathrm{~g})$ ). The risk premium in UIP compels bond holdings of the U.S. households to return to the initial level in the long term. They therefore use accumulated wealth to finance consumption and bond holdings begin to wane.

The next step is to implement welfare analysis. Following Schmitt-Grohe and Uribe (2007), it has become common to evaluate the welfare cost of policy A relative to policy $\mathrm{B}$, expressing the welfare difference in the percentage of consumption that households are willing to give to be as well off under policy A as under policy B. Later in this paper, I evaluate the value of the dollar peg as the percentage of consumption that households would be willing to pay for the dollar peg in order to be as well off under the dollar peg as under a floating exchange rate. To measure welfare in an identical way under flexible exchange rates, I now measure the welfare benefit of monetary policy as the percentage of consumption that households would be willing to pay for U.S. monetary expansion to remain as well off in the monetary expansion case as in the initial steady state.

As shown in Tervala (2012), the discounted present value (DPV) of the welfare benefit of monetary policy relative to the initial steady state (in case where a first-order approximation of the utility function is used), denoted by $\lambda_{D P V}$, is given by:

$$
\lambda_{D P V}=100 \times\left[\exp \left((1-\beta)\left(\sum_{s=t}^{\infty} \beta^{s-t}\left(\hat{C}_{s}-\ell_{0}^{1+1 / \varphi} \hat{\ell}_{s}\right)\right)-1\right] .\right.
$$

Equation (26) measures the percentage of initial consumption that a household is willing to pay for monetary policy expansion.

Table 2: Welfare effects under flexible exchange rates 


\begin{tabular}{|l|l|l|l|l|l|l|l|}
\hline & $\rho=0.5$ & $\rho=1$ & $\rho=2$ & $\rho=3$ & $\rho=4$ & $\rho=5$ & $\rho=6$ \\
\hline$\lambda_{D P V}$ & 0.023 & 0.36 & 0.42 & 0.44 & 0.45 & 0.46 & 0.46 \\
\hline$\lambda_{D P V}^{*}$ & 0.47 & -0.031 & -0.12 & -0.15 & -0.17 & -0.18 & -0.19 \\
\hline
\end{tabular}

Table 2 shows the welfare effects in the benchmark case $(\rho=2)$ and when using a set of alternative parameter values for the cross-country substitutability. It demonstrates that in the benchmark case, a U.S. interest rate reduction is a beggar-thy-neighbor policy that increases U.S. welfare at the dollar bloc's expense. The welfare benefit for U.S. households is $0.42 \%$ for their initial consumption.

Equation (26) shows that welfare is an increasing function of consumption and a decreasing function of employment. A U.S. terms of trade improvement explains the beggar-thy-neighbor welfare result. Monetary expansion increases in U.S. consumption with no equivalent increase in employment. As Figure 2(d) shows, the U.S. terms of trade improve even though prices for both U.S. exports and imports are set in dollars. In the short term, some firms can set a new price, and the relative increase in the demand curve for U.S. firms allows them to raise the relative price of their goods. Thus, U.S. terms of trade improve. This effect induces an increase in U.S. welfare. The drop in the dollar bloc's welfare stems from a deterioration of its terms of trade.

Table 2 shows that an increase in U.S. welfare is a robust finding. A very low cross-country substitutability $(\rho=0.5)$ implies an increase in the dollar bloc's welfare, however. Tille (2001) shows the cross-country substitutability determines whether the consumption switching toward U.S. goods is large enough to increase U.S. sales revenues, relative to the dollar bloc's revenues. In case of $\rho=0.5$ domestic and foreign goods are complements and the Marshall-Lerner condition is violated (see Tille 2001). In this case, a change in the international price ratio reduces the U.S. sales revenues and U.S. monetary expansion induces a U.S. current account deficit. The wealth effect of debt increases the relative U.S. labor supply (output) in the medium term and causes a U.S. terms of trade deterioration. This improves the dollar bloc's welfare. In the U.S., however, the benefits of higher output more than offset the welfare loss of the terms of trade deterioration, so the U.S. welfare effect remains positive.

Obstfeld and Rogoff (1995) find that a domestic monetary expansion benefits both the home and foreign country in cases where the cross-country substitutability is equal to the within-country substitutability and export prices are set in the producer's currency. Betts and Devereux (2000) demonstrate that when export prices are set in the local currency of the consumer, a monetary expansion is a beggar-thy-neighbor policy due to an improvement in 
the terms of trade. The results of this section show that under dollar pricing a monetary expansion decreases foreign welfare unless the cross-country substitutability is very low. The finding that the effects of monetary policy under dollar pricing on foreign welfare depend qualitatively on the crosscountry substitutability does not appear in the literature. Schmidt (2006) finds, setting the cross-country substitutability to 1.5, that a money supply shock is a beggar-thy-neighbor policy under dollar pricing. Table 2, however, shows that this result is not generally applicable.

Corsetti and Pesenti (2001) show that the effect of domestic monetary shocks on foreign welfare depends on the size of the elasticity of intertemporal substitution relative to the cross-country substitutability when export prices are set in the producer's currency. I assume a logarithmic utility for consumption, which implies that the elasticity of intertemporal substitution is one (this is a standard assumption and consistent with balanced growth). Therefore, one can generalize that a U.S. monetary shock increases the dollar bloc's welfare only when the cross-country substitutability is smaller than the elasticity of intertemporal substitution.

\subsection{Value of the dollar peg}

In this section, I analyze a case in which the dollar bloc pegs the currency to the dollar. Figure 3 (on page 38) shows the effects of a U.S. interest rate shock identical to one discussed in the previous section. The solid lines show the effects under flexible exchange rates, and the dashed lines depict the effects in the dollar peg case.

The dollar bloc must now mimic U.S. monetary policy. Figure 3 does not show the U.S. interest rate, but panel (h) depicts an interest rate in the dollar bloc that is identical to the U.S. rate. An interest rate cut in both regions implies a larger monetary expansion. Consequently, world consumption and output increase more under the dollar peg than they would under flexible exchange rates.

The dollar peg eliminates movement in the nominal exchange rate (Figure 3(e)), thus eliminating the expenditure switching effect that increases relative U.S. output under flexible exchange rates. Consequently, U.S. output increases by slightly less (Figure 3(a)) and the dollar bloc's output increases by more than they would under flexible exchange rates (Figure 3(b)). Erceg et al. (2011) developed a three-country model (the U.S., the dollar bloc and the rest of the world) and found that (their Figure 4) U.S. output is nearly invariant to assumptions about the dollar bloc's monetary policy. This finding is consistent with my finding.

The IMF (2013) has studied how the foreign output effect of U.S. mon- 
etary policy (an increase of 100 basis points in the policy rate) depends on the exchange rate regime. It found that contractionary U.S. monetary policy reduces foreign output substantially and significantly in countries with an exchange rate pegged to the U.S. dollar but the output effect for countries with a flexible exchange rate against the dollar is not significantly different from zero. The results of this papers, shown in Figure 3(b), are in line with the findings of the IMF (2013) in so far as the foreign output effect is substantial in the case of the dollar peg but close to zero in case of a flexible exchange rate. ${ }^{6}$

The dollar peg eliminates a distribution of income toward the U.S. and thus monetary expansion does not increase relative U.S. income and U.S. households cannot accumulate external wealth (see Figure 3(g)) for future consumption. This implies that the risk premium in UIP plays no role in adjustment dynamics. An identical increase in outputs implies that the international price ratio does not change. Consequently, Figure 3(f) shows, the U.S. terms of trade remain constant. This result is important for welfare, because the increase in U.S. welfare under the flexible exchange rate is based on improved terms of trade.

Figure 3(b) demonstrates that, compared to the flexible exchange rate case, the dollar bloc's consumption increases. The dollar bloc's monetary expansion and the elimination of the expenditure switching effect imply a greater increase in the dollar bloc's output. In addition, the fact that the dollar bloc's terms of trade do not deteriorate increases the dollar bloc's consumption, in comparison to the flexible exchange rate case.

Welfare increases equally in both the U.S. and the dollar bloc. They implement identical monetary expansion, consumption and employment increase equally, and the change in welfare therefore is identical. In addition, the size of the welfare gain ( $0.29 \%$ of initial consumption) does not depend on the cross-country substitutability.

The main innovation of this paper is to evaluate the value of the dollar peg, which I define as the percentage of consumption that households would be willing to pay for the dollar peg in order to be as well off under the dollar peg as under a floating exchange rate, assuming that labor supply remains constant.

Let $U_{D P V}^{F}$ be the DPV of welfare under floating exchange rates, and let

\footnotetext{
${ }^{6}$ This reasoning assumes that the effects of monetary policy are symmetric. Barnichon and Matthes (2017) find a difference between the effects of contractionary and expansionary monetary policy, consistent with the "pushing on a string" metaphor.
} 
$\left\{C_{s}^{F}, \ell_{s}^{F}\right\}_{s=t}^{\infty}$ be associated with the consumption and labor supply paths:

$$
U_{D P V}^{F}=\sum_{s=t}^{\infty} \beta^{s-t}\left[\log C_{s}^{F}-\frac{\ell_{s}^{1+\frac{1}{\varphi}}}{1+\frac{1}{\varphi}}\right] .
$$

Let $U_{D P V}^{P E G}$ be the DPV of welfare under the dollar peg, and let us define $\lambda_{D P V}^{P E G}$ as the DPV of the welfare benefit of the dollar peg. $U_{D P V}^{F}$ can be written as follows:

$$
\begin{aligned}
U_{D P V}^{P E G} & =\sum_{s=t}^{\infty} \beta^{s-t}\left[\log \left(\left(1+\lambda_{D P V}^{P E G}\right) C_{s}^{F}\right)-\frac{\left(\ell_{s}^{F}\right)^{1+\frac{1}{\varphi}}}{1+\frac{1}{\varphi}}\right], \\
U_{D P V}^{P E G} & =\frac{1}{1-\beta} \log \left(1+\lambda_{D P V}^{P E G}\right)+U_{D P V}^{F} .
\end{aligned}
$$

Solving for $\lambda_{D P V}^{P E G}$ and expressing the value of the dollar peg as the percentage of consumption (instead of a fraction of it) yields

$$
\lambda_{D P V}^{P E G}=100 \times\left[\exp (1-\beta)\left(U_{D P V}^{P E G}-U_{D P V}^{F}\right)-1\right] .
$$

First-order approximations of the utility function are

$$
\begin{aligned}
& d U_{D P V}^{P E G}=U_{D P V}^{P E G}-U_{0}=\sum_{s=t}^{\infty} \beta^{s-t}\left(\hat{C}_{s}^{P E G}-\ell_{0}^{1+1 / \varphi} \hat{\ell}_{s}^{P E G}\right), \\
& d U_{D P V}^{F}=U_{D P V}^{F}-U_{0}=\sum_{s=t}^{\infty} \beta^{s-t}\left(\hat{C}_{s}^{F}-\ell_{0}^{1+1 / \varphi} \hat{\ell}_{s}^{F}\right)
\end{aligned}
$$

where $d$ denotes change and the superscript $P E G$ and $F$ serve to denote the dollar peg and floating exchange rate. Making use of Equations (29) and (30), Equation (28) can be written as follows:

$$
\begin{aligned}
\lambda_{D P V}^{P E G}= & 100 \times\left[\operatorname { e x p } \left(( 1 - \beta ) \left(\sum_{s=t}^{\infty} \beta^{s-t}\left(\hat{C}_{s}^{P E G}-\ell_{0}^{1+1 / \varphi} \hat{\ell}_{s}^{P E G}\right)\right.\right.\right. \\
& \left.\left.-\left(\sum_{s=t}^{\infty} \beta^{s-t}\left(\hat{C}_{s}^{F}-\ell_{0}^{1+1 / \varphi} \hat{\ell}_{s}^{F}\right)\right)\right)-1\right] .
\end{aligned}
$$

Equation (31) measures the value of the dollar peg as the percentage of consumption that the domestic household is willing to pay for the dollar peg in order to be as well off under the dollar peg as under the floating exchange rate. Consequently, a positive value for the dollar peg implies that households are better off under the dollar peg. 
Table 3: Value of the dollar peg

\begin{tabular}{|l|l|l|l|l|l|l|l|}
\hline & $\rho=0.5$ & $\rho=1$ & $\rho=2$ & $\rho=3$ & $\rho=4$ & $\rho=5$ & $\rho=6$ \\
\hline$\lambda_{D P V}^{P E G}$ & 0.27 & -0.067 & -0.13 & -0.14 & -0.15 & -0.16 & -0.17 \\
\hline$\lambda_{D P V}^{* P E G}$ & -0.18 & 0.32 & 0.41 & 0.44 & 0.46 & 0.47 & 0.48 \\
\hline
\end{tabular}

Table 3 shows that the value of the dollar peg is negative for the U.S., unless the cross-country substitutability is very low $(\rho=0.5)$. U.S. households are willing to pay part of their consumption to eliminate the dollar peg. The households in the dollar bloc are better off under the dollar peg, unless the cross-country substitutability is very low. This provides a rationale for the dollar bloc to peg the currency to the U.S. dollar. To the best of my knowledge, these results are all new, since the existing literature contains no analyses of the value of the dollar peg relative to cases where countries adhere to the Taylor rule.

The positive value of the dollar peg for the dollar bloc stems from the ability of the U.S. to improve its terms of trade at the dollar bloc's expense under flexible exchange rates. The dollar peg prevents this, and in essence renders the dollar bloc a closed economy: its consumption and output increase by equally. This increases welfare in the model. Due to imperfect competition, the levels of consumption and output are inefficiently low, and interest rate reductions bring them temporarily closer to an efficient level, thereby increasing welfare. The positive value of the dollar peg comes from the fact that the dollar peg prevents the U.S. from deteriorating the dollar bloc's terms of trade and forces monetary expansion in the dollar bloc.

The value of the dollar peg, however, is negative for the dollar bloc in cases where the cross-country substitutability is very low $(\rho=0.5)$. In this case, under the flexible exchange rate, a change in the international price ratio reduces (increases) the U.S. (the dollar bloc's) sales revenues, because the Marshall-Lerner condition is violated, and the wealth effect causes a U.S. terms of trade deterioration, increasing welfare in the dollar bloc. The dollar peg eliminates this and consequently the value of the dollar peg for the dollar bloc becomes negative when the cross-country substitutability is sufficiently low.

As Table 3 shows, the value of the dollar peg is typically negative for the U.S. When the dollar peg is used, U.S. interest rate reductions do not raise U.S. consumption by improving U.S. terms of trade. The dollar peg prevents the U.S. from improving its terms of trade at the dollar bloc's expense. Consequently, the dollar peg is harmful to the U.S. Interest rate reductions increase U.S. welfare, but the value of the dollar peg is nonetheless negative.

The value of the dollar peg is positive for the U.S. if the cross-country substitutability is very low $(\rho=0.5)$. As mentioned, U.S. interest rate 
reductions under the flexible exchange rate induce a U.S. terms of trade deterioration in cases of a very low cross-country substitutability. The dollar peg eliminates this and therefore increases welfare, compared with the flexible exchange rate case. Consequently, the value of the dollar peg for the U.S. becomes positive when the cross-country substitutability is sufficiently low.

As mentioned, the spillover effects of monetary policy depend on the size of the elasticity of intertemporal substitution, which is one in this model, relative to the cross-country substitutability. More generally, the value of the dollar peg depends on the relative sizes of these parameters. Erceg at al. (2010) argue that, while in the macro literature the elasticity of intertemporal substitution is typically set to one, microeconomic estimates suggest that it is in the range of 0.2 to 0.7. As mentioned in Section 3, empirical estimates for the cross-country substitutability vary, but they are almost always larger than one. This suggest that for the realistic parameter combinations of the cross-country substitutability and the elasticity of intertemporal substitution, the value of the dollar peg is indeed negative for the U.S. and positive for the dollar bloc.

Betts and Devereux (2000) find that a domestic monetary expansion is a beggar-thy-neighbor policy in cases of local currency pricing. If the foreign country also implements a monetary expansion, the exchange rate will be unchanged and both countries will be better off. The findings of this paper complement those of Betts and Devereux (2000). The analysis of this paper shows that foreign countries, in a model with dollar pricing and a consumption index in which the cross-country substitutability can differ from the within-country substitutability, are not necessarily better off if they also implement a monetary expansion. In addition, the value of the dollar peg is typically negative for the U.S. That is, a monetary expansion also by a foreign country is not beneficial to the home country. ${ }^{7}$

\subsection{Sensitivity analysis}

The next step analyzes the sensitivity of the main results to changes in potential key features of the model. First, I change the behavior of the central bank of the dollar bloc in the flexible exchange rate case, holding everything else the same. Second, I change the behavior of the central bank of the dollar

\footnotetext{
${ }^{7}$ This model extends the framework of Betts and Devereux (2000) in several ways. The first extension is the introduction of staggered price setting in the form of Calvo (instead of the assumption that prices are set for one period). Tervala (2012), however, shows that Calvo pricing does not change the main results of Betts and Devereux (2000). The second extension is the introduction of home bias in consumption. This extension, however, does not qualitatively change the result regarding the value of the dollar peg.
} 
bloc in the dollar peg case, holding everything else at the same values as in the baseline. Third, I vary only the parameters of the model.

The benchmark economy for welfare comparisons is the one with the flexible exchange rate case, under which both countries follow a Taylor rule with interest rate smoothing. This may be too narrow and it is interesting to use different monetary policy rules for the dollar bloc as a benchmark to examine the welfare benefits of the dollar peg. I analyze the consequences of three alternative monetary policy rule for the dollar bloc in the case of a flexible exchange rate regime. The first rule is the Taylor without interest rate smoothing (TRw/oS, for short), i.e. $\mu_{1}=0$ in equation (11). The second is the inflation-based Taylor rule (ITR, for short) without interest rate smoothing, i.e. $\mu_{1}=\mu_{3}=0$. The third rule is the domestic inflationbased Taylor rule (DITR, for short). It can be expressed in a log-linear form as follows ${ }^{8}$

$$
\hat{\imath}_{t}^{*}=\mu_{2} \Delta \hat{P}_{t}^{* D B}
$$

Table 4: Sensitivity analysis: the value of the dollar peg

\begin{tabular}{|c|c|c|c|}
\hline Row & Modification & $\lambda_{D P V}^{P E G}$ & $\lambda_{D P V}^{* P E G}$ \\
\hline 1 & Baseline & -0.13 & 0.41 \\
\hline 2 & TRw/oS & -0.13 & 0.41 \\
\hline 3 & ITR & -0.13 & 0.41 \\
\hline 4 & DITR & -0.13 & 0.41 \\
\hline 5 & Soft dollar peg & -0.089 & 0.29 \\
\hline 6 & $\gamma=0.5$ & -0.064 & 0.18 \\
\hline 7 & $\theta=9$ & -0.13 & 0.34 \\
\hline 8 & $\varphi=0.5$ & -0.14 & 0.40 \\
\hline 9 & $\varphi=2$ & -0.12 & 0.43 \\
\hline 10 & $n=0.55$ & -0.13 & 0.40 \\
\hline
\end{tabular}

Row 1-4 of Table 4 show the value of the dollar peg under the four different policy rules for the dollar peg in the case where the cross-country substitutability is two. The table shows that it is a robust finding that the dollar peg is harmful to the U.S. but beneficial for the dollar peg in the case of expansionary U.S. monetary policy, unless the cross-country substitutability is very low. Under these policy rules the dollar bloc's monetary policy has very limited impact on the value of the dollar peg. The main reason for this is that under all these rules the response of the dollar bloc's central bank is very mild.

\footnotetext{
${ }^{8}$ Gali and Monacelli (2005) use the second and third rule to analyze monetary policy for a small open economy.
} 
The $\operatorname{IMF}(2013,108)$ finds, as mentioned in Section 2, that it "cannot reject the possibility that the interest rate of a pegging country reacts one to one to movements in the federal funds rate, as theory would predict for a perfectly credible peg". In the previous analyses, I have assumed that the dollar bloc pegs the exchange rate by mimicking U.S. monetary policy $\left(i_{t}=i_{t}^{*}\right)$. However, the IMF (2013) finds that a surprise change of 100 basis points in the U.S. policy rate is typically followed by a change of about 70 basis points in countries that peg their currency to the U.S. dollar. Next I check the sensitivity of the main results to a change in the behavior of the central banks of the dollar bloc where there is a dollar peg. Based on the finding of the IMF (2013), I assume that a decrease of 100 basis points in the U.S. interest rate is followed by a decrease of 70 basis points in the dollar bloc's interest rates. This can be done by assuming that the central banks of the dollar bloc follow the baseline Taylor rule, equation (11), and the size of the dollar bloc's monetary policy shock is 0.7 times the U.S. monetary shock, i.e. $\epsilon_{t}^{*}=0.7 \epsilon_{t}$. I refer to this case as the soft dollar peg. As in the baseline simulations, to evaluate the value of the dollar peg, I contrast the flexible exchange rate case in which the central bank of the dollar bloc follows the Taylor rule with interest rate smoothing, with an alternative with the soft dollar peg.

Figure 4 (on page 39) and row 5 of Table 4 shows the effects of a U.S. interest rate shock in the case of the soft dollar peg. The dollar bloc must now mimic U.S. monetary policy. Figure $4(\mathrm{~h})$ shows that an interest rate in the dollar bloc is decreased by 70 basis points. The dollar depreciates because the U.S. interest rate is temporarily low relative to the dollar bloc's interest rates. Therefore, the soft dollar peg does not eliminating the expenditure switching effect. Consequently, U.S. output increases more than the dollar bloc's output. In this model, the ratio of the output effect in the dollar bloc to the output effect in the U.S. is 0.71 . The IMF (2013) found that the ratio of the peak output effect of a U.S. monetary policy shock in countries with a dollar peg to the peak output effect of a U.S. monetary policy shock in the U.S. is 0.75 . So the model with the soft dollar peg can in essence match the empirically observed ratio.

Table 4 shows that the value of the soft dollar peg is positive (negative) for the dollar bloc (the U.S.) but smaller than in the baseline case of the dollar peg. The changes in the value of the dollar peg are caused by the behavior of the terms of trade. Figure 3(f) shows that under the soft dollar peg, unlike under the dollar peg, the U.S. terms of trade improve. However, the value of the soft dollar peg is negative (positive) for the U.S. (the dollar bloc) because the soft dollar peg limits the ability of the U.S. to improve its terms of trade at the dollar bloc's expense. 
Finally, I change parameter values, holding everything else the same as in the baseline simulations. Row 6 shows the value of the dollar peg when the price rigidity parameter $(\gamma)$ is reduced from 0.75 to 0.5 . This implies the average duration of prices is reduced from four quarters to two. The values of the dollar peg move closer to zero because the real effects of monetary policy are smaller in the case of greater price flexibility.

Row 7 shows the value of the dollar peg in a case where the withincountry substitutability $(\theta)$ increased from 6 to 9. For instance, Gali's (2015) textbook uses this value. The within-country substitutability affects only the initial steady state and thus welfare results, but not the response of endogenous variables. According to Equation (25), the lower the withincountry substitutability is, the lower the initial levels of employment, output and consumption are. Therefore, the lower within-country substitutability is, the more an increase in employment and consumption of a given size increases welfare. Table 4 shows that the value of the dollar peg for the dollar bloc drops to 0.34. The value of the dollar peg for the U.S. drops so little that due to rounding it is still roughly -0.13 .

In row 8, the Frisch elasticity is reduced from 1 to 0.5 , while in row 9 it is increased to 2 . I find small quantitative changes in the value of the dollar peg.

After the Great Recession, the relative size of China's economy has increased. In row 10, the relative of the U.S. is reduced from 0.6 to 0.55 , holding the import-to-GDP ratios constant. The values of the dollar peg are robust to changes in the relative size of the U.S. economy.

\subsection{Discussion}

The positive value of the dollar peg for emerging economies provides a rationale for fixing their currencies to the dollar during a period of expansionary U.S. monetary policy. The model is linear, so the effects of contractionary U.S. monetary policy would be the opposite. The negative value of the dollar peg during contractionary U.S. monetary policy implies that the dollar bloc policy makers should choose differently to U.S. interest rate increases. In this case, the dollar bloc should be more willing to let their currencies float in order to avoid the appreciation of the dollar bloc's currencies in line with the dollar.

Figure 1 (on page 36) shows the yuan to one U.S. dollar exchange rate and U.S. interest rates. Mertens and Shultz (2017) argue-based on IMF's reports on exchange arrangements-that, while China has closely monitored the yuan's movements against the dollar, it has not always followed a tight dollar peg. China allowed mild fluctuations in the nominal exchange rate 
from 2006 to 2008 when China's exchange rate policy was classified as a crawling peg to the U.S. dollar. ${ }^{9}$ Figure 1 shows that the Fed increased the interest rate in 2006. Moreover, from 2006 to 2008, the deviation from the Taylor rule implies that U.S. monetary policy was contractionary. In 2007, the Fed began to cut the interest rate and by the beginning of 2008 it was below the interest rate implied by the Taylor rule, implying that U.S. monetary policy become expansionary. Figure 1 shows that China returned to the tight dollar peg in mid-2008 and Mertens and Shultz (2017) emphasize that between 2008 and 2010, the yuan was stabilized relative to the U.S. dollar, based on IMF's classification of exchange rate arrangements.

Mertens and Shultz (2017) write that from 2011 to 2015 China's exchange rate policy was a crawl-like arrangement relative to the U.S. dollar, allowing for wider fluctuations in the exchange rate. Figure 1 shows that by the end of 2010, the deviation of the actual interest rate from the Taylor rule was very small. After the interest rate increase of the Fed in 2015, China has allowed even wider fluctuations in the dollar exchange rate. Mertens and Shultz (2017) highlight that in 2015, the central bank of China said that its exchange rate policy is based on an exchange rate index of 13 currencies. Following this, in 2016, the IMF changed China's classification to an arrangement where the exchange rate flexibility is limited relative to a group of currencies. This allows for wider fluctuations in the dollar exchange rate. China's exchange rate policy supports some support the view that while the tight dollar peg may not be optimal all the time- especially when the Fed raises interest ratesit could be optimal when the Fed cuts interest rates aggressively and U.S. monetary policy is looser than the Taylor rule implies.

The theme of this paper is related to a classic question of whether pegging a country's exchange rate is beneficial. Friedman (1953) finds that shocks require the adjustment of relative price levels between countries and that because internal prices are highly inflexible, the exchange rate should be flexible. Feldstein (1992) argues that domestic deflation is likely to require a period of increased unemployment, so a decline in the nominal exchange rate would prove beneficial. Devereux and Engel $(2003,766)$ argue that "[t]his reasoning has led to the well-known traditional recommendation to monetary policy makers in open economies: an optimal monetary policy in an open economy requires exchange-rate flexibility." Lahiri et al. (2008), however, say that the classical finding in the world of sticky prices and perfect capital

\footnotetext{
${ }^{9}$ It is likely that the gradual appreciation of the yuan was related to the threat of a tariff of $27.5 \%$, which was the precise midpoint of a range of estimates of the yuan's undervaluation at that time, on all Chinese imports put forward by two U.S. senators in 2005. The yuan, however, appreciated by the required amount to neutralize the threat (Economist 2009).
} 
mobility is that a flexible (fixed) exchange rate is optimal if shocks are mainly real (monetary). The optimal exchange rate regime depends therefore on the type of disturbance.

The recent literature has shown that the choice depends also on the currency of export pricing. Devereux and Engel (2003) found that a fixed (floating) exchange rate regime is desirable under local (producer) currency pricing for a small economy in the presence of country-specific real shocks in cases where the cross-country substitutability is one. The most directly related work to this paper is Goldberg and Tille (2009). They developed a three-country model (the U.S. and the dollar bloc consisting Asia and Latin America) and analyzed the choice of the exchange rate regime in the face of productivity shocks in cases where the cross-country substitutability is one. They found that the dollar bloc remains better off under flexible exchange rates than under a unilateral peg.

The recent literature, however, has not addressed the question of whether a fixed exchange rate is optimal for the foreign country in cases of domestic monetary shocks. The results of this paper show that the optimal choice of exchange rate regime in the face of monetary shocks is predicated by crosscountry substitutability. It is optimal for emerging economies to fix their exchange rates in cases of U.S. monetary expansion, unless cross-country substitutability is very low. A limitation of the paper is that no other types of shocks are modelled. So one should remember that the optimal choice of exchange rate regime depends on the importance of foreign monetary shocks and the other types of shocks.

The existing literature describes various motivations for exchange rate pegs in emerging economies. However, Mishkin (1998) argues that costs exceed benefits, such as providing an anchor for monetary policy. These costs include the loss of an independent monetary policy, exposure to the transmission of the anchor country's shocks, the increased likelihood of speculative attacks and weakened accountability in pursuing anti-inflationary policies. The biggest problem is that an exchange rate peg can increase financial instability and heighten the potential for financial crises. Frankel (1999), on the other hand, argues that the optimal exchange rate regime varies depending on the specific circumstances of the country and the circumstances of the time period in question.

During the global financial crisis, the effects of aggressive U.S. monetary policy on macroeconomic and financial stability in the dollar bloc have drawn attention. Rajan (2011) and Wolf (2008) argue that U.S. monetary policy leads to an overheating of the dollar bloc and rising inflation. Rajan (2011, 107) argues that these lead to "very real problems". On the other hand, McKinnon and Schnabl (2012) and Schnabl (2010) analyze the costs and 
benefits of the dollar peg for China, East Asia and the rest of the World and argue that the dollar peg plays a crucial role in the pursuit of macroeconomic stability. This model supports the view of Rajan (2011) and Wolf (2008) that exposure to U.S. monetary policy may lead to an overheating of the dollar bloc: in the model, the dollar bloc's output increases substantially, in comparison to the flexible exchange rate case (recall Figure 3(b)). However, the dollar peg is optimal, from the welfare point of view.

Figure 3(j) shows that under the dollar peg, expansionary U.S. monetary policy leads to rising inflation in the dollar bloc. This result is consistent with that of Erceg et al. (2011), who find that the response of core inflation in the dollar bloc depends qualitatively on whether the dollar bloc pegs the currency or adheres to the Taylor rule. Thus, Rajan's (2011) and Wolf's (2008) arguments that expansionary U.S. monetary policy may be too aggressive for the dollar bloc, thereby creating inflation, seems justified.

The model, however, does not support the view that an overheating of the dollar bloc and inflation would lead to real problems: the boom is followed by a slightly negative output gap in the medium term because short term inflation has reduced the real wage below its steady state value. A wellknown property of standard dynamic general equilibrium models, however, is that they cannot generate boom-bust cycles or financial instability. Bordo and Meissner (2012) find that the two key determinants of credit booms are economic expansion and low interest rates, and credit booms heighten the probability of a financial crisis. The dollar peg may force monetary expansion in the dollar bloc in the expansionary phase of the business cycle, which may be too aggressive for it. A limitation of the paper is that the dollar peg may create financial instability that the present model cannot capture.

\section{Conclusions}

In this paper, I analyze the consequences of the dollar peg during expansionary U.S. monetary policy. The dollar peg has important implications both for the U.S. and the dollar bloc. A key finding is that the value of the dollar peg is typically positive for the dollar bloc, since it prevents the U.S. improving its terms of trade at the expense of the dollar bloc. This provides a rationale for fixing the exchange rate to the dollar during a period of expansionary U.S. monetary policy. So China's return to the tight dollar peg in 2008, when U.S. monetary policy deviated from the Taylor rule, may have been a reaction to a beggar-thy-neighbor policy of the Fed. The dollar peg, however, may lead to an overheating of the economy and rising inflation in the dollar bloc. 
The value of the dollar peg is negative for the U.S., unless the crosscountry substitutability is very low. This provides a rationale for the U.S. criticizing the dollar bloc's exchange rate policy. However, dollar pegs in emerging economies-including China-only reduce the welfare gain of expansionary U.S. monetary policy to the U.S. The model therefore seems to explain quite well the behavior of China and the U.S.: China returned to a tight dollar peg during the U.S. financial crisis, when the Fed cut interest rates aggressively and China's exchange rate policy was a target for criticism in the U.S. 


\section{References}

[1] Abed, George., Nuri Erbas, and Behrouz Guerami, 2003, "The GCC Monetary Union: Some Considerations for the Exchange Rate Regime," IMF Working Paper No. 03/66 (Washington: International Monetary Fund).

[2] Barnichon, Regis and Christian Matthes, 2017, "Functional Approximations of Impulse Responses: New Insights into the Asymmetric Effects of Monetary Policy," mimeo.

[3] Bergin, Paul. R, 2006, "How Well Can the New Open Economy Macroeconomics Explain the Exchange Rate and Current Account?" Journal of International Money and Finance, Vol. 25, No. 4, pp. 675-701.

[4] Betts, Caroline, and Michael Devereux, 2000, "Exchange Rate Dynamics in a Model of Pricing-to-Market," Journal of International Economics, Vol. 50, No. 1, pp. 215-244.

[5] Bluedorn, John. C., and Christopher Bowdler, 2011, "The Open Economy Consequences of U.S. Monetary Policy," Journal of International Money and Finance, Vol. 30, No. 2, pp. 309-336.

[6] Bordo, Micheal D., and Christopher M. Meissner, 2012, "Does Inequality Lead to a Financial Crisis?," Journal of International Money and Finance, Vol. 31, No. 8, pp. 2147-2161.

[7] Bordo, Michael D., Owen F. Humpage, and Anna J. Schwartz, 2012, "Epilogue: Foreign Exchange Market Operations in the Twentieth Century," NBER Working Paper No. 17984 (Cambridge, Massachusetts, National Bureau of Economic Research).

[8] Caceres, Carlos, Yan Carrière-Swallow, Ishak Demir, and Bertrand Gruss, 2016, "U.S. Monetary Policy Normalization and Global Interest Rates," IMF Working Paper No. 16/195 (Washington: International Monetary Fund).

[9] Calvo, Guillermo A, 1983, "Staggered Prices in a Utility Maximizing Framework," Journal of Monetary Economics, Vol. 12, No. 2, pp. 383398. 
[10] Corsetti, Giancarlo and Paolo Pesenti, 2001, "Welfare and Macroeconomic Interdependence," Quarterly Journal of Economics Vol. 116, No. 2, pp. $421-455$.

[11] Cheung, Yin-Wong, Dickson Tam, and Matthew S. Yiu, 2007, "Does the Chinese Interest Rate Follow the US Interest Rate?" International Journal of Finance and Economics, Vol. 93, No. 1, pp. 52-67.

[12] Clarida, Richard, Jordi Galí, and Mark Gertler, 2000, "Monetary Policy Rules and Macroeconomic Stability: Evidence and Some Theory," Quarterly Journal of Economics, Vol. 115, No. 1, pp. 147-180.

[13] Devereux, Michael, B. and Charles Engel, 2003, "Monetary Policy in the Open Economy Revised: Price Setting and Exchange Rate Flexibility," Review of Economic Studies, Vol. 70, No. 4, pp. 765-784.

[14] Erceg, Christopher, Christopher Gust and David López-Salido, 2010, "The Transmission of Domestic Shocks in Open Economies," in ed by Jordi Gali and Mark J. Gertler International Dimensions of Monetary Policy (Chicago, University of Chicago Press).

[15] Erceg, Christopher, Luca Guerrieri, and Steven B. Kamin, 2011, "Did Easy Money in the Dollar Bloc Fuel the Global Commodity Boom?" International Journal of Central Banking, Vol. 7, No. 1, pp. 131-160.

[16] Federal Reserve of Atlanta, 2017, "Taylor Rule Utility," available at https://www.frbatlanta.org/cqer/research/taylor-rule.aspx?panel=1

[17] Federal Reserve Bank of St. Louis, 2017, Fred Economic Data available at https://fred.stlouisfed.org/

[18] Feenstra, Robert C., Maurice Obstfeld, and Katheryn N. Russ, 2017, "In Search of the Armington Elasticity," Review of Economics and Statistics, forthcoming.

[19] Feldstein, Martin, 1992. The Case Against the EMU. The Economist, June 13.

[20] Frankel, Jeffrey, 1999, "No Single Currency Regime is Right for All Countries or at All Time," Essays in International Finance (Princeton, Princeton University).

[21] Frankel, Jeffrey, 2010. China-US Currency Issues. Presentation. Ash Center, June 8, 2010. Available at 
http://www.hks.harvard.edu/fs/jfrankel/ChinaUSCurrenciesCLDJune2010.ppt (retrieved on June 10th, 2012).

[22] Friedman, Milton, 1953, "The Case for Flexible Exchange Rates," in Essays in Positive Economics, (Chicago, University of Chicago Press).

[23] Gali, Jordi, 2015. Monetary policy, inflation and the business cycle: An introduction to the New Keynesian framework and its applications, 2nd Edition (Princeton, Princeton University).

[24] Gali, Jordi, and Tomasso Monacelli, 2005, "Monetary Policy and Exchange Rate Volatility in a Small Open Economy," Review of Economic Studies, Vol. 72, No. 3, pp. 707-734.

[25] Glick, Reuven, and Michael Hutchison, 2009, "Navigating the Trilemma: Capital Flows and Monetary Policy in China," Journal of Asian Economics, Vol. 20, No. 3, pp. 205-224.

[26] Gopinath, Gita, and Roberto Rigobon, 2008, "Sticky Borders," Quarterly Journal of Economics, Vol. 123, No. 2, pp. 531-575.

[27] Goldberg, Linda S., and Cédric Tille, 2008, "Vehicle Currency Use in International Trade," Journal of International Economics, Vol. 76, No. 2, pp. 177-192.

[28] Goldberg, Linda S., and Cédric Tille, 2009, "Macroeconomic Interdependence and the International Role of the Dollar," Journal of Monetary Economics, Vol. 56, No. 7, pp. 990-1003.

[29] Hooper, Peter, Karen Johnson, and Jaime Marquez, 2000, "Trade Elasticities for the G-7 Countries," Princeton Studies in International Economics No. 87 (Princeton, Princeton University).

[30] IMF, 2013, World Economic Outlook: Transitions and Tensions. (Washington, DC, IMF)

[31] Keane, M. and R. Rogersson, 2012. "Micro and Macro Labor Supply Elasticities: A Reassessment of Conventional Wisdom," Journal of Economic Literature Vol. 50, No. 2, pp. 464-476.

[32] Klein, Paul, 2000, "Using the Generalized Schur Form to Solve a Multivariate Linear Rational Expectations Model," Journal of Economic Dynamics and Control Vol. 24, No. 10, pp. 1405-1423.

[33] Krugman, P, 2010, Taking On China. New York Times, March 15th. 
[34] Koivu, Tuuli, 2009, "Has the Chinese Economy Become More Sensitive to Interest Rates? Studying Credit Demand in China," China Economic Review, Vol. 20, No. 3, pp. 455-470.

[35] Lahiri, Amartya, Rajesh Singh and Carlos A. Vegh, 2008. "Optimal Exchange rate Regimes: Turning Mundell-Fleming's Dictum on its Head," in ed by C. M. Reinhart, C. A. Végh, A. Velasco, Money, Crises, and Transition: Essays in honor of Guillermo Calvo (Cambridge, MA, The MIT Press).

[36] Lane, Philip, 2011, "External Imbalances and Macroeconomic Policy in New Zealand," IIIS Discussion Paper No. 376 (Dublin, University of Dublin).

[37] Ma, Guonan, and Robert N. McCauley, 2008, "Do China's Capital Controls Still Bind? Implications for Monetary Autonomy and Capital Liberalization," in ed. by. Eichengreen, B., Chul Park, Y. and Wyplosz, C. China, Asia, and the New World Economy, (Oxford, Oxford University Press).

[38] McCallum, Bennett, 2001, "Software for RE Analysis," computer software available at http://wpweb2.tepper.cmu.edu/faculty/mccallum/research.html.

[39] McKinnon, Ronald and Gunther Schnabl, 2012, "China and Its Dollar Exchange Rate: A Worldwide Stabilising Influence?," World Economy, Vol. 35, No. 6, pp. 667-693.

[40] Mertens, Thomas M. and Patrick Shultz, 2017, "China's Exchange Rate Policies and U.S. Financial Markets," FRBSF Economic Letter 2017-28.

[41] Mishkin, Frederic. S, 1998, "The Dangers of Exchange-Rate Pegging in Emerging-Market Countries," International Finance, Vol. 1, No. 1, pp. 81-101.

[42] Obstfeld, Maurice, and Kenneth Rogoff, 2002, "Global Implications of Self-Oriented National Monetary Rules," Quarterly Journal of Economics, Vol. 117, No. 2, pp. 503-535.

[43] Prasad, Eswar, S., 2008, "Monetary Policy Independence, the Currency Regime, and the Capital Account in China," in ed by. Goldstein, M. and Lardy, M. Debating China's Exchange Rate Policy (Washington, DC, Peterson Institute for International Economics) 
[44] Rajan, Raghuram, 2011, "Currencies Aren't the Problem: Fix Domestic Policy, Not Exchange Rates," Foreign Affairs, Vol. 90, March/April, pp. 104-116.

[45] Rogoff, Kenneth, 2008, "The World Cannot Grow Its Way Out of This Slowdown," Financial Times, July 29.

[46] Rotemberg, Julio, and Micheal Woodford, 1992, "Oligopolistic Pricing and the Effects of Aggregate Demand on Economic Activity," Journal of Political Economy, Vol. 100, No. 6, pp. 1153-1207.

[47] Schmidt, Caroline, 2006, "International Transmission Effects of Monetary Policy Shocks: Can Asymmetric Price Setting Explain the Stylized Facts?" International Journal of Finance and Economics, Vol. 11, No. 3, pp. 205-218.

[48] Schmitt-Grohe, Stephanie, and Martin Uribe, 2003, "Closing Small Open Economy Models," Journal of International Economics, Vol. 61, No. 1, pp. 163-185.

[49] Schmitt-Grohe, Stephanie, and Martin Uribe, 2007, "Optimal Simple and Implementable Monetary and Fiscal Rules," Journal of Monetary Economics, Vol. 54, No. 6, pp. 1702-1725.

[50] Schnabl, Gunther, 2010, "The Role of the Chinese Dollar Peg for Macroeconomic Stability in China and the World Economy," University of Jena, Working Papers on Global Financial Markets No. 13 (Jena, University of Jena).

[51] Stiglitz, Joseph, 2008, "Responding to the Crisis," Presentation, Financial Regulation by the Initiative for Policy Dialogue and Brooks World Poverty Institute, Manchester, July, 2008.

[52] Stiglitz, Joseph, 2010, "Why Easier Money Won’t Work," Wall Street Journal, October 23, 2010.

[53] Taylor, John, B, 1993, "Discretion versus Policy Rules in Practice," Carnegie-Rochester Conference Series on Public Policy, Vol. 39, December, pp. 195-214.

[54] Tervala, Juha, 2012, "International Welfare Effects of Monetary Policy," Journal of International Money and Finance, Vol. 31, No. 2, pp. 356376. 
[55] Tille, Cedric, 2001, "The Role of Consumption Substitutability in the International Transmission of Monetary Shocks," Journal of International Economics, Vol. 53, No. 2, pp. 421-444.

[56] The Economist, 2010, "China Policy Yuanimpressed," July 1.

[57] The Economist, 2011, "Poor Dollar Standard: Has the Downgrade Shaken Loyalty to the Greenback?" August 13.

[58] Wolf, Martin, 2008, "How Imbalances Led to Credit Crunch and Inflation," Financial Times, June 17.

[59] World Bank, 2016, Data available online at http://data.worldbank.org/.

[60] Zhang, Wenlang. 2009, "China's monetary policy: Quantity versus Price Rules," Journal of Macroeconomics, Vol. 31, No. 3, pp. 473-484. 
Figure 1: Actual Fed funds rate, the Taylor rule prescription and the Chinese yuan to one U.S. dollar exchange rate, quarterly data, source: Federal Reserve Bank of Atlanta (2017) and Federal Reserve Bank of St. Louis (2017)

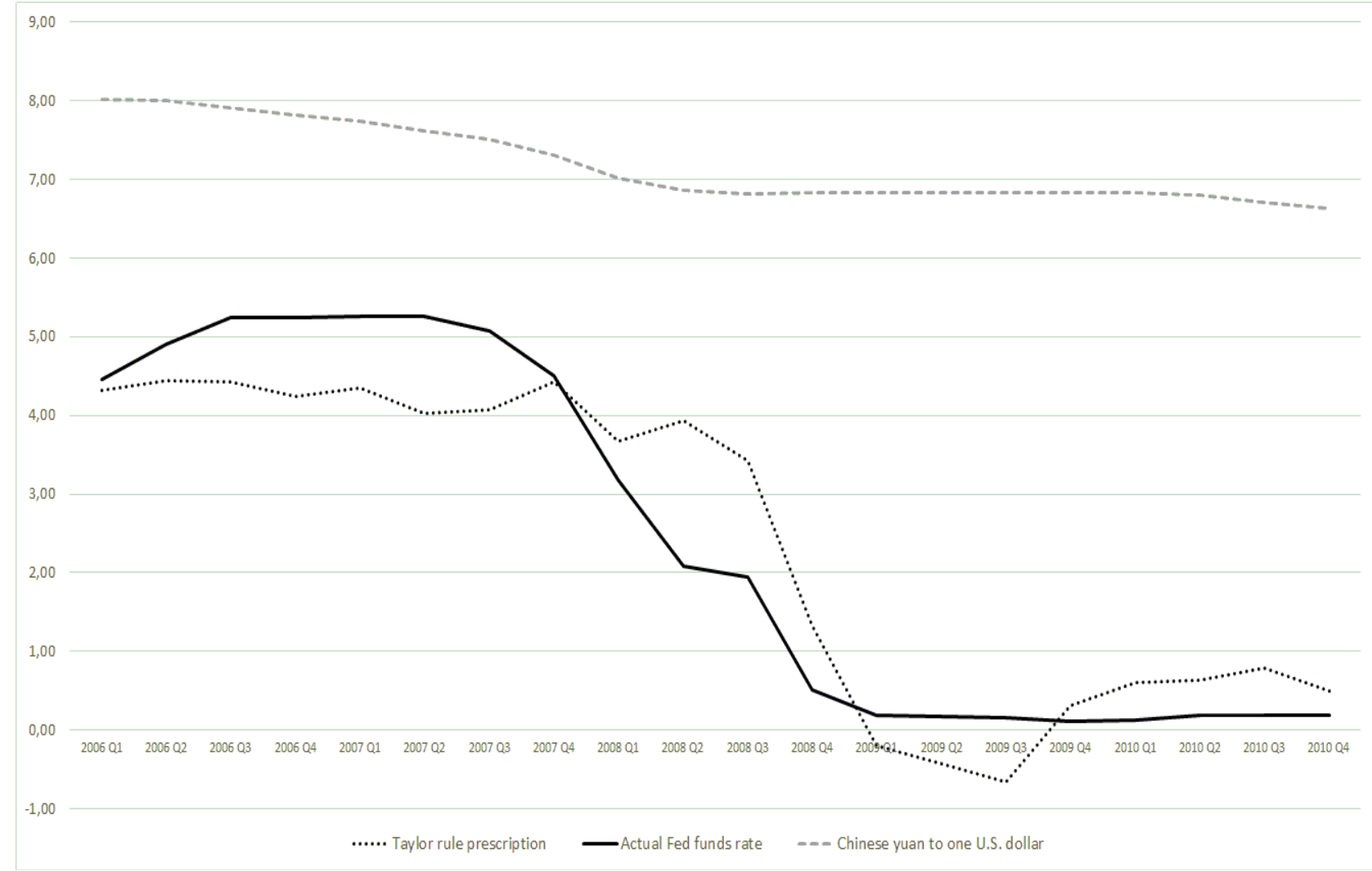


Figure 2: Dynamic effects of a U.S. monetary shock under flexible exchange rates
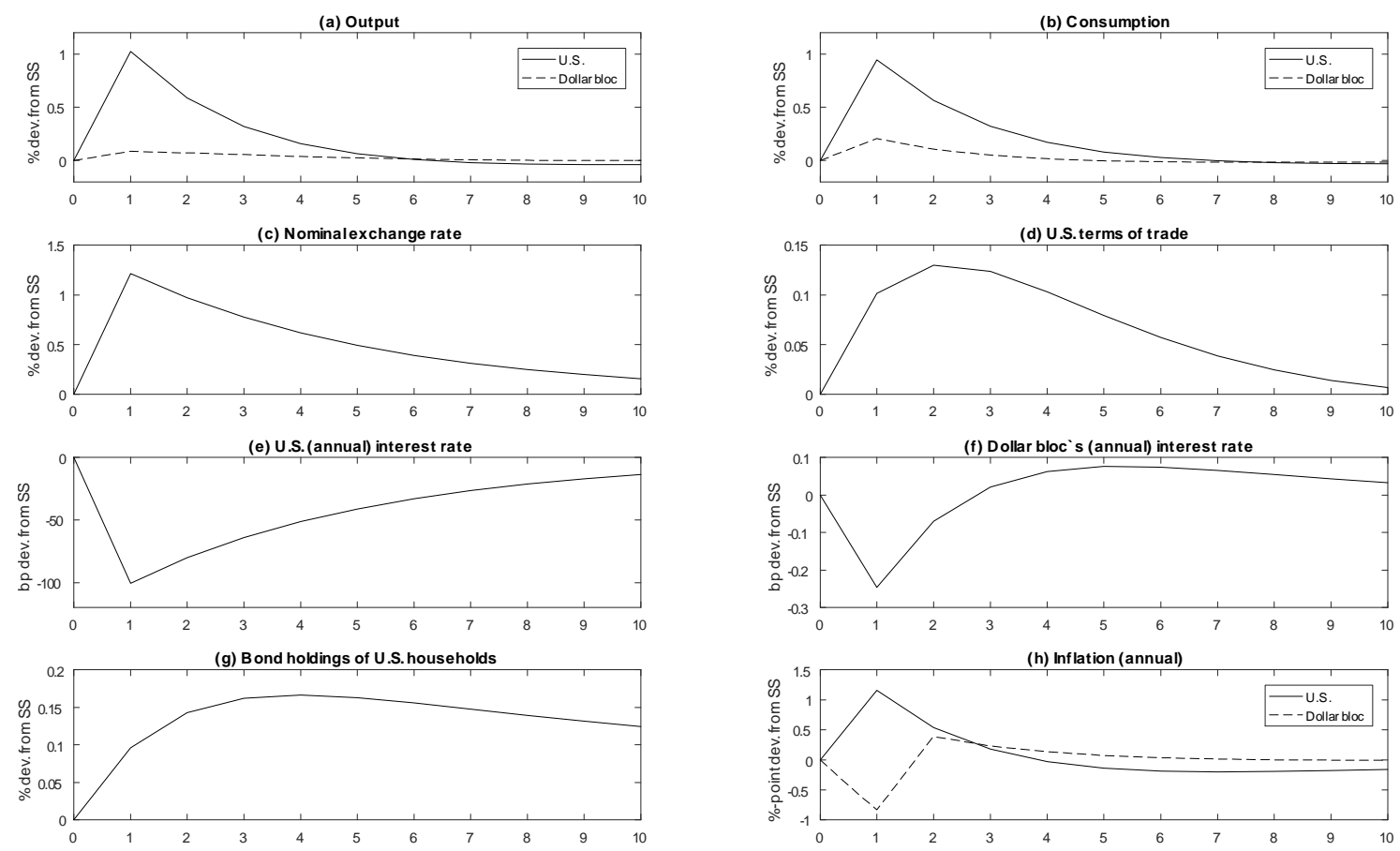
Figure 3: Dynamic effects of a U.S. monetary shock under the dollar peg
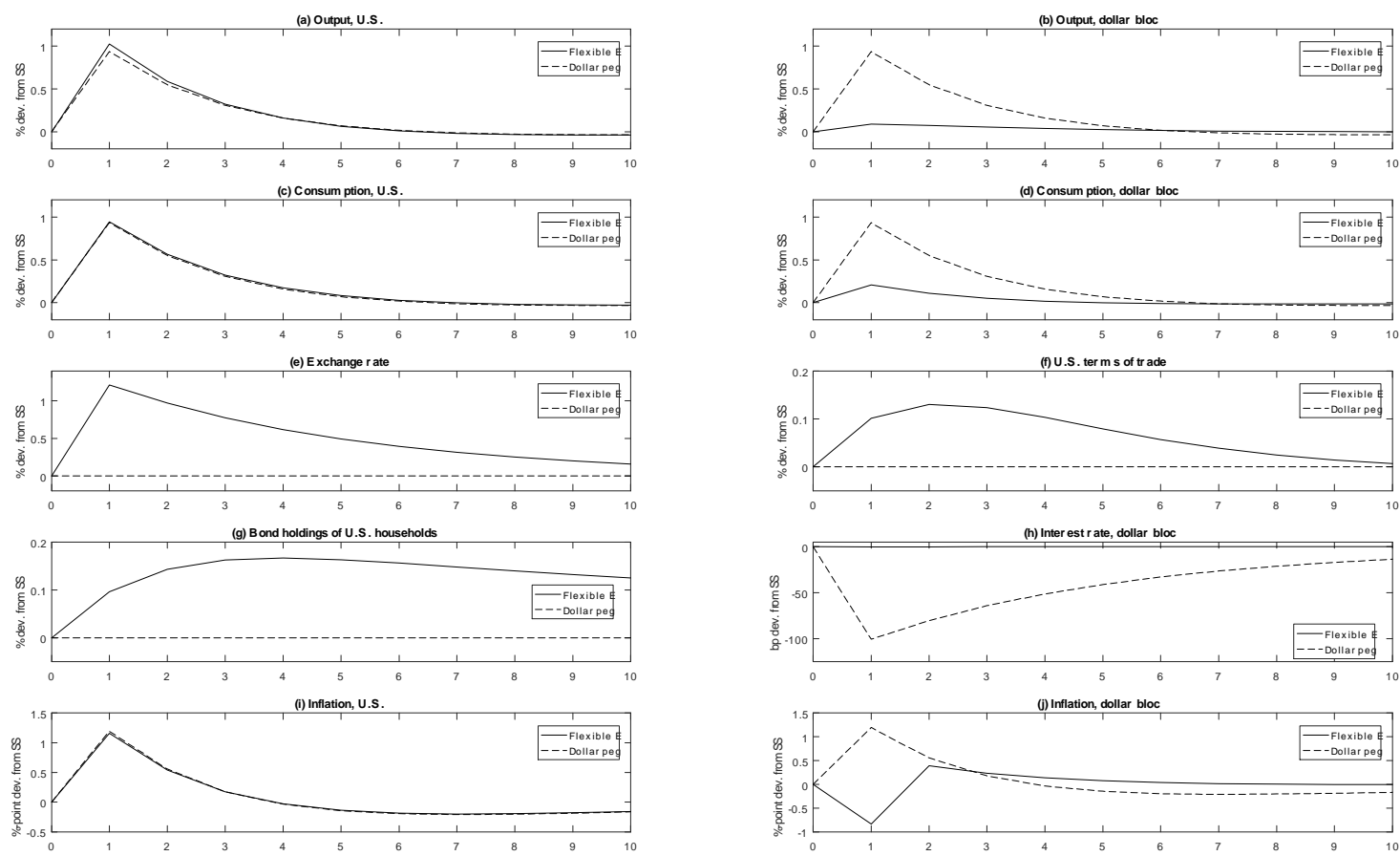
Figure 4: Dynamic effects of a U.S. monetary shock under the soft dollar peg
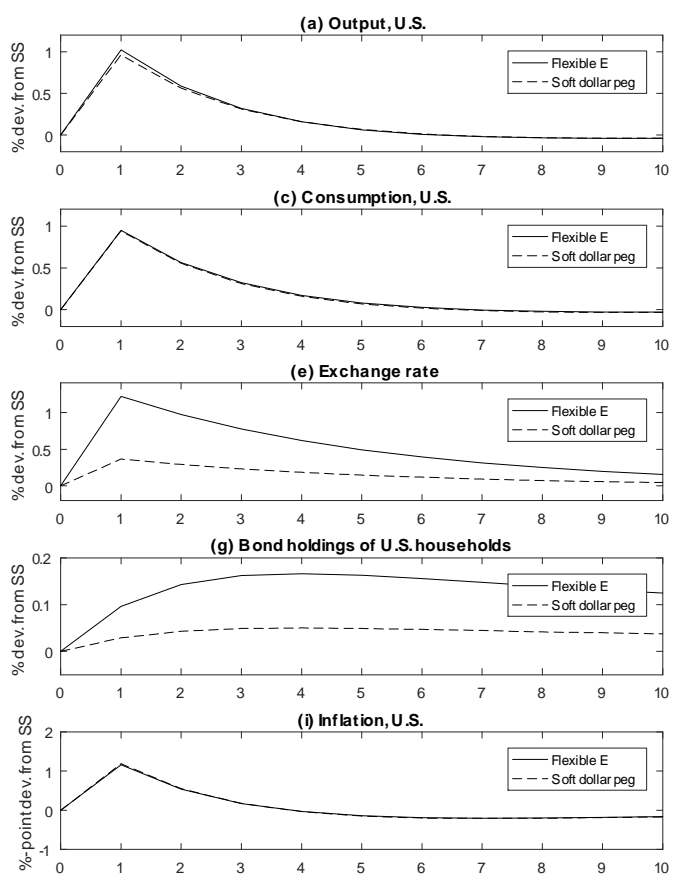
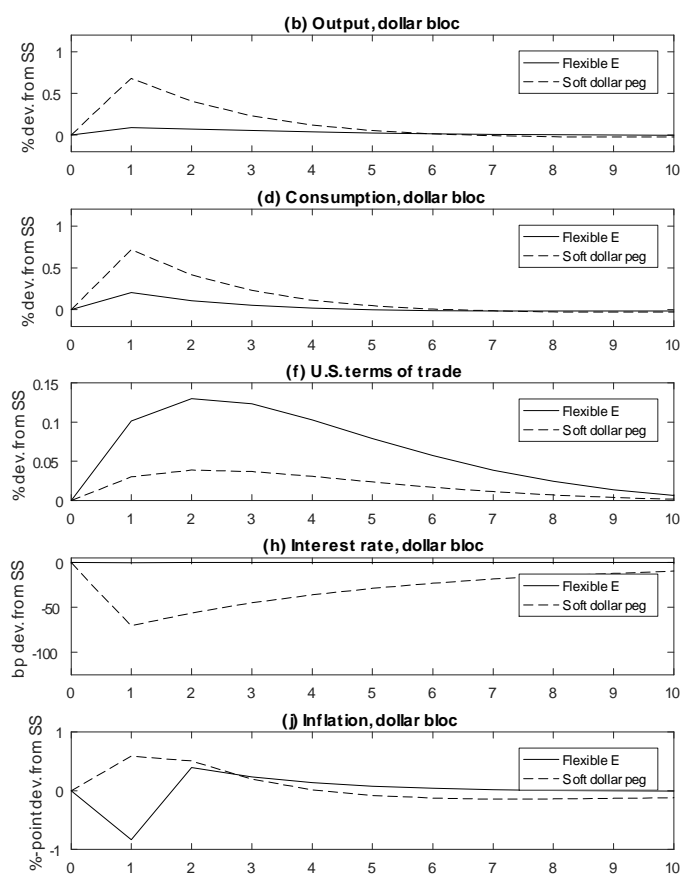

Figure 5: 